Conference Report

\title{
Assessment of Impediments and Factors Affecting Waste Management: A Case of Accra Metropolis
}

\author{
Clifford James Fagariba ${ }^{1, *}$ and Shaoxian Song 2,3 \\ 1 School of Resources and Environmental Engineering, Wuhan University of Technology, Wuhan, \\ Hubei 430070, China \\ 2 Hubei Provincial Collaborative Innovation Center for High Efficient Utilization of Vanadium \\ Resources, Wuhan University of Technology, Luoshi Road 122, Wuhan, Hubei 430070, China; \\ ss851215@whut.edu.cn \\ 3 Hubei Key Laboratory of Mineral Resources Processing and Environment, Wuhan University of \\ Technology, Luoshi Road 122, Wuhan, Hubei 430070, China \\ * Correspondence: cfagariba@yahoo.com
}

\begin{abstract}
Solid waste management in Accra is a major challenge to the Metropolitan Authorities and inhabitants. The rapidly increasing population coupled with poor capacity of the municipal and private waste management companies to management waste effectively has created issues of environmental concern. Due to poor wastement managements systems, most household dispose waste discriminately leading to floods and health issues. The study showed that about $60 \%$ of household waste is organic materials which has the potential to be converted to compost for agriculture purpose. Meanwhile plastics and rubbers which litters the environment as well as blocking major storm drains and gutters hence creating huge environmental hazard is made of $11 \%$ of the total component of most household waste generated daily. The study also revealed that among the methods of disposing waste, dumping waste in skip containers located at authorized places was the preferred means of disposing waste by household though others also dispose waste by other means such as burying and burning. Inadequate skip containers per population of household in an area coupled with irregularity of tracks picking these containers makes skip containers dumping site ugly scene, hence creating health issues. Among the constraints that impact negatively on sustainable waste management in Accra Metropolis, economic constraints was perceived as the main challenge which affect efficient waste management as currently the country is going through serious economic challenges so government does not release money timely to fund projects which waste management is key. Most donor partners that use to support the government with funds have either reduced or redrawn their services as they have no confidence in the state of Ghana economy. Aside the constrains, the study also indicated that factors such as poor public attitude towards waste management, poor enforcement of sanitation by-laws, inadequate and untimely release of government funds were also seen as the main factors affecting waste management.
\end{abstract}

Keywords: constraints; factors; household; solid waste management

\section{Introduction}

All over the world, countries are battling with waste management and governments are investing huge sums of money to tackle waste issues. Waste management comes with huge cost but if left unattended, the environmental hazard and health issues would be unbearable especially in developing countries. The pertinent issue with waste management is that, products that are produced in volumes to meet preferences of global population explosions do not come with unique way of disposal, hence creating challenges during waste recycling. For efficient global waste management, technology should be advanced to cater for waste especially E- waste that are often discarded as 
scraps. So far as life is concern, humanity cannot do without creating waste. A rapidly increasing global population leads to waste generation. Producers convert available resources to meet demands. Additionally, as technology advances, people's preferences change.

Governments in most developing countries have resorted to using their own money to fund waste management projects as external support for waste management is now unsustainable. Unsustainability waste management projects is due to various technical, financial, institutional, economic, and social constraints faced by both the recipient countries/cities and external support agencies. Therefore, in order to ensure the sustainability of collaborative projects, the various constraints of both developing countries and external support agencies should be carefully examined so as to get suitable solutions aiming at addressing waste management challenges.

Accra is the capital city of Ghana. Its population of 2,291,352 generates about 2,000 tons per day (TPD) of municipal solid waste (MSW), of which over $75 \%$ is collected and transported to the Tema dump site at a cost of US\$ 4.45 million per year (GHS 7.7 million). The non-collected waste is openly burnt or dumped in storm water and sewage water drains by residents. Open burning of waste is common even in high income communities due to distance to skip sites or authorised dumping sites.

In 2014, the Accra Metropolitan Authority (AMA) spent $82 \%$ of its internally generated funds (IGF) on solid waste management. Most of this funding was spent on collection, transportation and disposal at landfill sites. Waste is collected using different types of vehicles such as tricycle, small trucks and large trucks with or without compactors. The major reasons for poor waste collection coverage are due to inadequate or late payment of operational funds and ineffective monitoring of performance of private contractors. Among other attempts to increase collection coverage, currently there is AMA and Zoom lion collaboration project to provide plastic waste containers to individual households for free. However, this project may not achieve it main objective as some households have turned their new dustbins for storage facility.

Over the last ten years, AMA has used at least seven temporary dumping grounds within the city perimeter to dispose the city's solid waste, thus creating dangers to public health and the environment. This led to public outrage, hence compelling AMA and Environmental Protection Agency (EPA) to close the last in-city landfill site at Achimota a suburb of Accra. All dump sites which were located inside the city severely impacted public health, the environment and quality of life. The indigenes of Accra have the habit of confronting public authorities to oppose the disposal of wastes in their neighborhood. The city is now served by the new Tema sanitary landfill, located at Kpone, 30 kilometers from the city. This facility was constructed by Zoom lion Ghana.

\subsection{Statement of the Problem}

A typical solid waste management system in a developing country displays an array of problems, including low collection coverage and irregular collection services, crude open dumping and burning without air and water pollution control, the breeding of flies and vermin, and the handling and control of informal waste picking or scavenging activities. These public health, environmental and management problems are caused by various factors which serve as constrains to the development of effective solid waste management systems.

Waste collection in Accra is divided into two parts: $80 \%$ of the city's waste collection is handled by private contractors, whereas the other 20\% is handled by AMA's WMD. In 1992, soon after the start of economic reforms in Ghana, a pilot project initiated by World Bank started privatisation of waste management in Accra. The percentage of private waste collection has since increased from nearly $11 \%$ to the current level of $60 \%$ of all waste generated. Simultaneously, the waste collection coverage in Accra has increased from $51 \%$ to the current level of $70 \%$ due to population increase and urbanization. The Waste Management Department (WMD) under AMA is unable to fulfill its obligation of collecting $30 \%$ of the city's waste due to inadequate funds, poor technology and other socioeconomic constraints hence generating environmental hazards (Osei, 2010). As a result of poor waste management, flooding, malaria and outbreak of cholera is common in Accra Metropolis. 
Waste is collected using different types of vehicles ranging from manually driven tricycles, small trucks equipped with compactors, large trucks and large trucks equipped with compactors. The company Zoom Lion (ZL) has been using tricycles to access areas with narrow lanes and small trucks to access hilly regions with narrow lanes. Large trucks equipped with compactors are being used in places like residential areas, vegetable markets and corporate areas which generate large quantities of waste every day. According to Adjei et al (2013) the city of Accra generates about 2,000 tons per day (TPD) of solid waste, out of which $70 \%$ is collected and transported to Tema dump site at a cost of US $\$ 3.45$ million per year (GHS 6.7 million) ( $12 \mathrm{~km}$ by road from the city centre). Uncollected waste is openly burnt or dumped in storm water and sewage water drains. Open burning of waste is common even in high income communities.

Solid waste management has over the years been a challenge among city authorities in Ghana. Particularly in the two big cities (Accra and Kumasi), where over 4,000 tons of solid waste is generated daily. Waste management departments still grapple with the collection and proper disposal of this huge amount of solid waste. Undoubtedly, the capacity of AMA and Zoom Lion has been greatly overwhelmed by the ever-increasing amounts of waste in the Metropolis due to increase in population. Consequently, heaps of solid waste is common sights in cities and suburbs mostly near market centers, slums and low income settlements. This presents a host of problems as these huge piles of waste threaten human life and the environment as well. Although, numerous researchers have attributed this principally to inadequate resources and weak institutional capacities, there seems to be some disregarded factors that also contribute substantially to the current issue. It is in this regard that the research seeks to find out the main constraints and factors impeding waste management in Accra Metropolis.

Solid waste management is the process of collecting, storing, treatment and disposal of solid wastes in such a way that they are harmless to humans, plants, animals, the ecology and the environment generally. Solid waste can be defined as "any substance or object in solid form which the holder discards or intends to discard. The 'holder' can either be the producer of the waste or be in possession of the waste (Chalam, et al 2009). Waste, however, is very subjective; one person may deem an item to be waste whilst another might see it as a resource (Williams, 2005). Research by Hristovski et al (2007) also highlighted due to resource appraisal, what seems to be waste could be a resource to another person depending on the technology or skill one has to convert that into a useful product for human use. The dynamic nature of consumer/end user products, packaging materials, environmental regulations and public attitudes has made the development of solid waste management strategies an increasingly complex task (DEA, 2012). The existence of waste pickers/scavengers creates often an obstacle to the operation of solid waste collection and disposal services mostly because their activities scatter gathered refuse and the lighter refuse like the polythene bags fly away. However, if organized properly, their activities can be effectively incorporated into a waste recycling system to aid waste management (Osei, et al 2010). Such approach is required for sustainable development of solid waste management programmes in developing countries where technology of reuse or recycling is still low.

As a result of a low priority given to the waste management sector, the institutional capacity of local government agencies involved in solid waste management is generally weak, particularly in small cities and towns. Local by-laws regarding solid waste management is not also well enforced resulting in waste dumping at unauthorized places. Perpetrators of this unlawful act go unpunished instead of facing full rigorous of the law to deter others from that. Local government institutions are not provided with clear mandates and sufficient resources to fulfill their mandatory objectives. In large metropolitan areas where there is more than one local government, coordination among the local governments is critical to achieve the most cost-effective alternatives for solid waste management in the area. For instance, the sitting of a solid waste transfer station or disposal facility for use by more than one local government is cost-effective due to the possibility of economic of scale. However, as these facilities are usually considered unwanted installations and create not-in-mybackyard (NIMBY) syndromes among residents, no local government is willing to locate waste 
disposal facility within its boundary. The lack of coordination among the local governments often leads to disintegrated and unsustainable programs for solid waste management.

Good waste management system must involve all stakeholders from the local level to the national level to enhance collaboration. As most Africa countries continue to dispose about $80 \%$ of solid waste at landfill sites and recycling only about $20 \%$, there is the need for good outline procedure in the waste management sector, starting from sensitization of residents about the need to dispose waste in appropriate manner so as to make collection and transfer to final disposal site easy, environmentally friendly and cost-effective (Sanko,2012). According to UNEP (2013), sensitization of local residents should include encouraging separation of waste into recyclable and non-recyclable for easy disposal and recycling. Furthermore, equipment such as dustbins, disposal tracts with or without compactors, tricycles, skip containers and other tools that contribute to efficient solid waste management should be supplied regularly and obsolete ones should be replaced. Fuel allocations and maintenance should be properly planned to ensure regular waste collections. The new paradigm shift framework which researchers and many international organizations deem feet to curb high rate of waste generation globally should follow the following trend: (1) Prevent the production of waste or reduce the amount generated; (2) Reuse the toxicity or reduce the negative impact of waste generated; (3) Reuse in their current forms the material recovered from the waste stream; (4) Recycle, compost or recover materials for use as direct or indirect inputs for new products; (5) Recover energy by incineration, anaerobic digestion or similar process; (6) Reduce the volume of waste prior to disposal; (7) Disposal of residual solid waste in environmentally sound manner, generally landfills.

Figure 1 gives a clear picture of the new paradigm shift that serve as framework of many international organizations and governments globally.

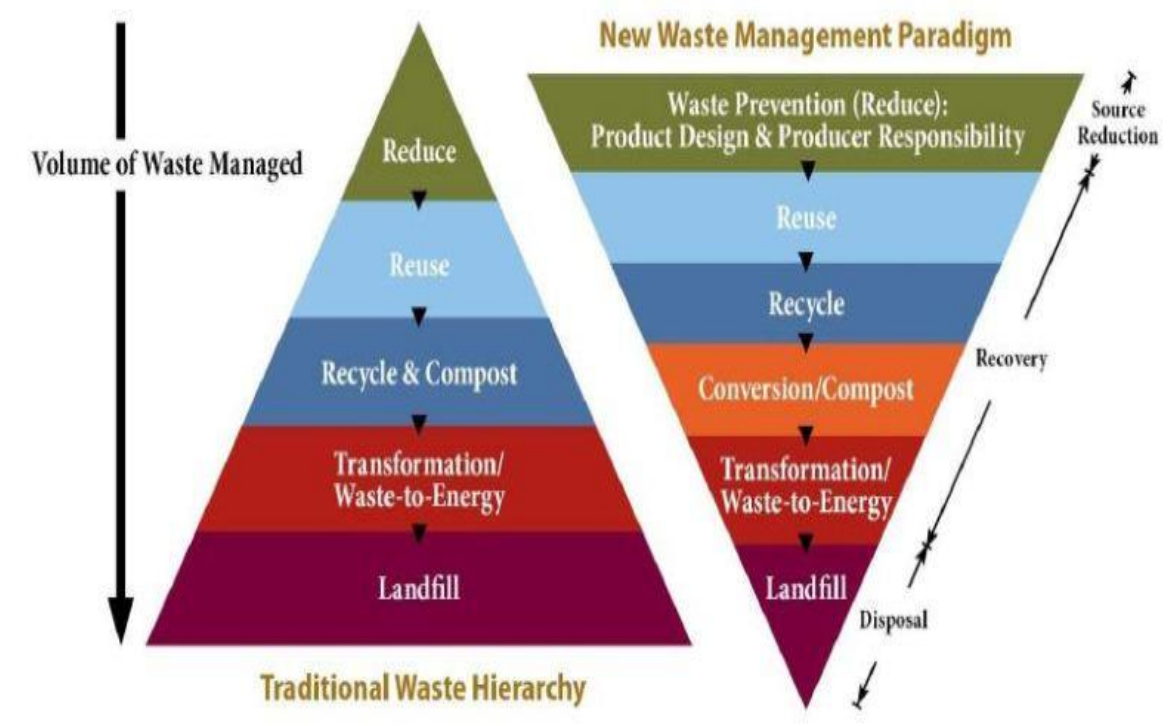

Figure 1. Integrated solid waste management hierarchy.

\subsection{Theoretical Framework of the Study}

It is important to recognize that, the major portion of solid waste comes from domestic sources. However its proper disposal depends heavily on availability of skips containers, dustbins and attitudes of the people. The waste that is disposed by households has to be collected and transported for final disposal. Poor coordination between major partners or stakeholders in waste management industry leads to the selection of inappropriate technology in terms of the local climatic and physical conditions, financial and human resource capabilities and social or cultural acceptability (OkotOkumu, 2012). This can lead to inefficiency thereby wasting the resource allocations and making the project unsustainable. The framework adopted by this study is that, there should be coordination among all the stakeholders directly or indirectly involving in waste management: thus starting from 
the source of waste generation (household) to the landfill site or recycling plant. This implies that, for proper functioning of any solid waste management project to achieve its objective, the main component of the waste management technology used should involve local stakeholders who have knowledge on the kind and nature of waste generated and the local ways of disposing off the waste appropriately. Many solid waste technology is often selected without due consideration to its relevance in the overall solid waste management system. Hence the coverage of solid waste collection services may be so low that solid waste generated is dumped at many unapproved sites (e.g., open areas, water channels, streets, etc.).Efficient waste management systems ensures that all the processes, technology, policies and key stakeholders coordinate effectively to promote prudent solid waste management. The framework perceive waste management as core environmental challenge and for matter it should be tackled holistically integrated manner, where there would be collaboration among all stakeholders and government so as to generate raw materials for industries, energy and compost as well as creating jobs for masses. Main source of waste such as household and industries should be collected and dispose in a proper way while stakeholders must also ensure that the appropriate ways of waste management practices earmarked to enhance efficiency in waste management should not be undermined. Government should also be instrumental in putting policies in place enhancing coordination among all the sectors of waste management scheme and also be able to strategically reform any policy within the waste management chain programs that may pose threat to overall waste management system.

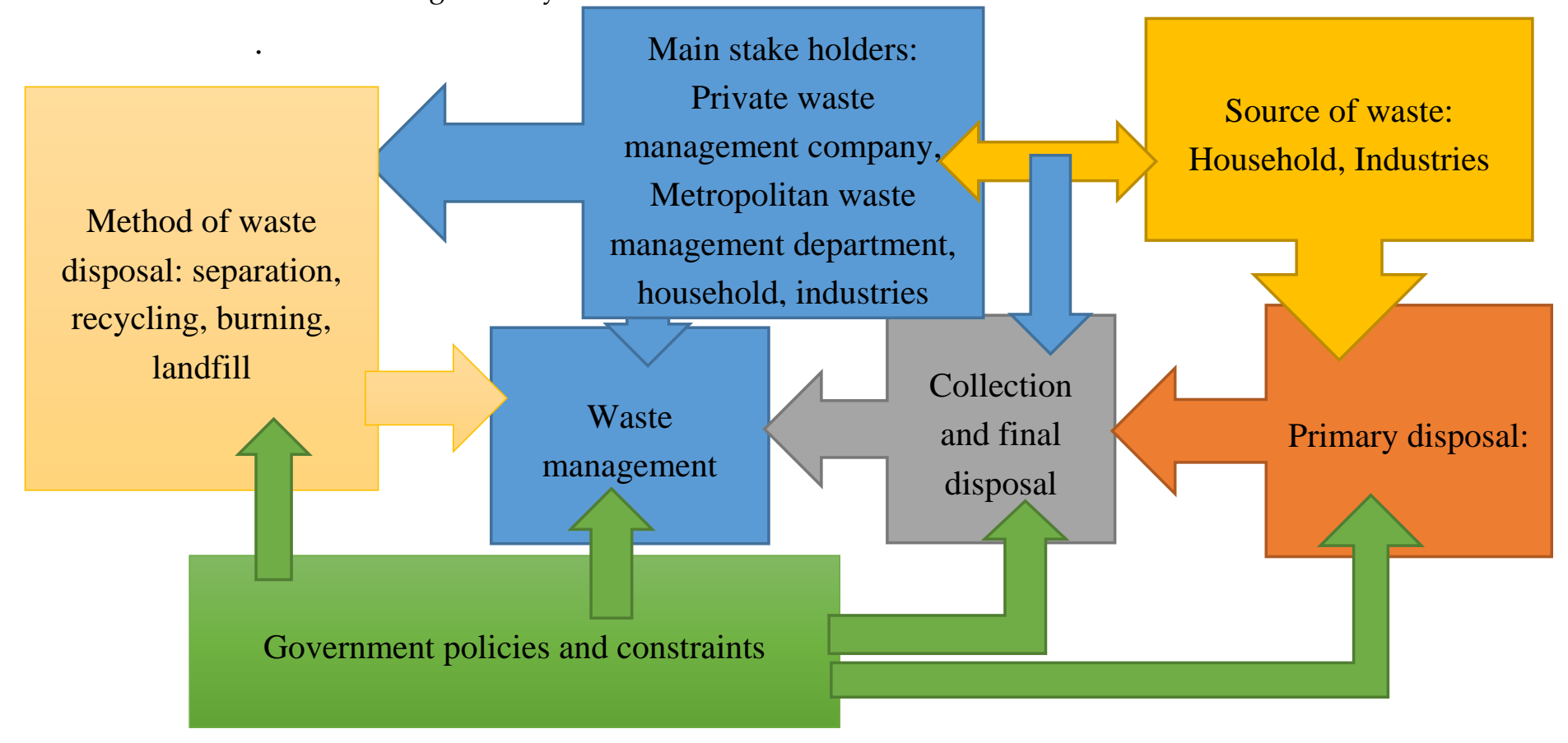

Figure 2. Theoretical framework of the stud.

\section{Study Area}

According Ghana Statistical Service(2014) updated report, the population of Accra Metropolis is 2,291,352 people . Females' population is 1.188 million while 1,103,352 is males giving a population density of 12 persons $/ \mathrm{sqkm}^{2}$. It covers a total land area of about $894 \mathrm{~km}^{2}(345.18 \mathrm{sq}$ mile) which is about $25 \%$ of the total landmass of the Greater Accra Region. It population growth rate is $4.2 \%$ per annum due to rapid rural urban migration as against $2.3 \%$ for the national. The average household size is approximately 10 persons.

The population is dominated by the work force between 15 to 64 years representing about $44.7 \%$ of the entire population. Small proportion of the labour force is above 64 years. The proportion of population below age 15 years is about $44.7 \%$ while that of the elderly represents about $6.3 \%$. Figure 
3 and 4 respectively below shows the map of Ghana and Accra Metropolis indicating location and main towns in Accra.

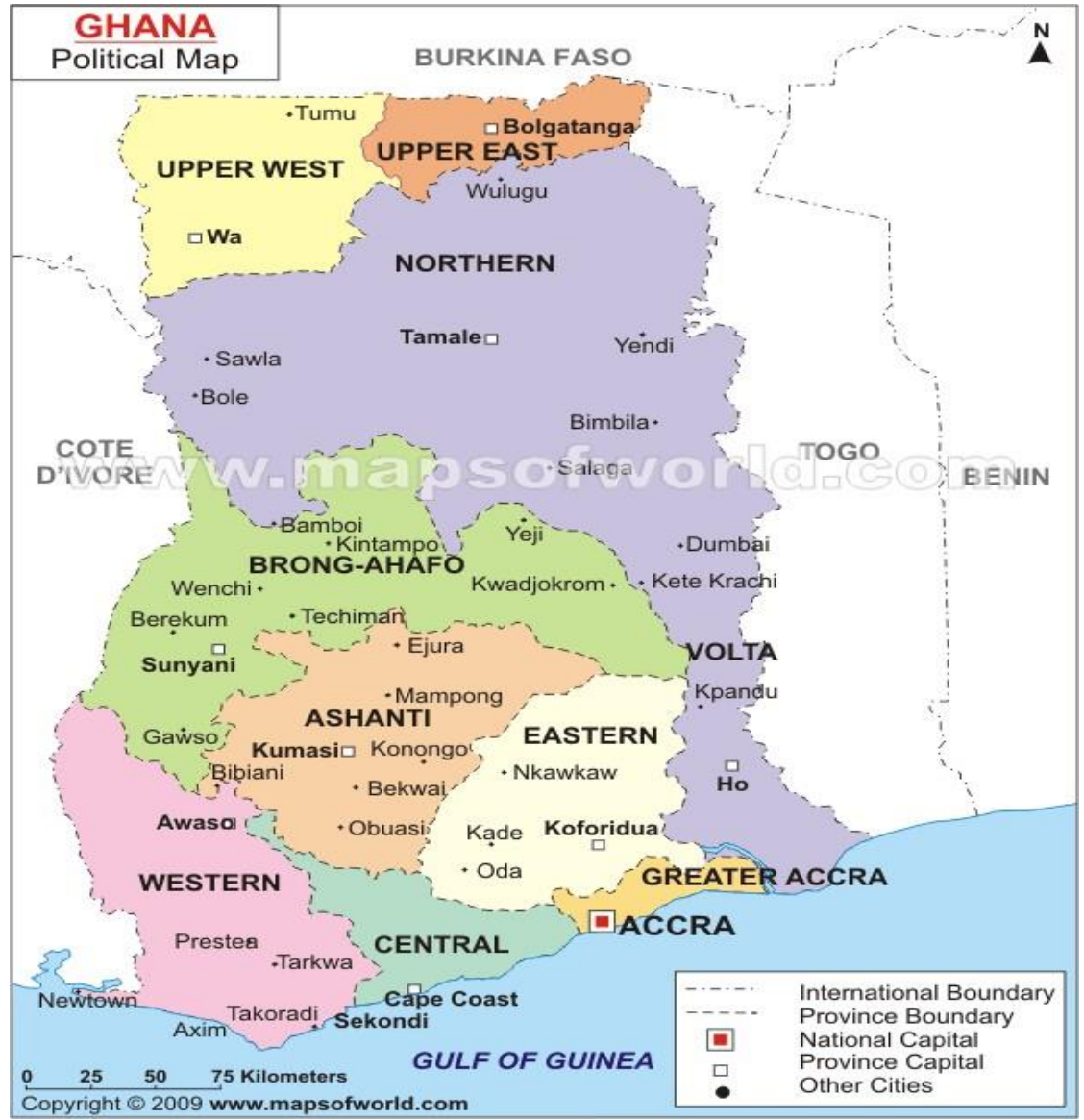

Figure 3. Map of Ghana (Source: www.mapsofworld.com).

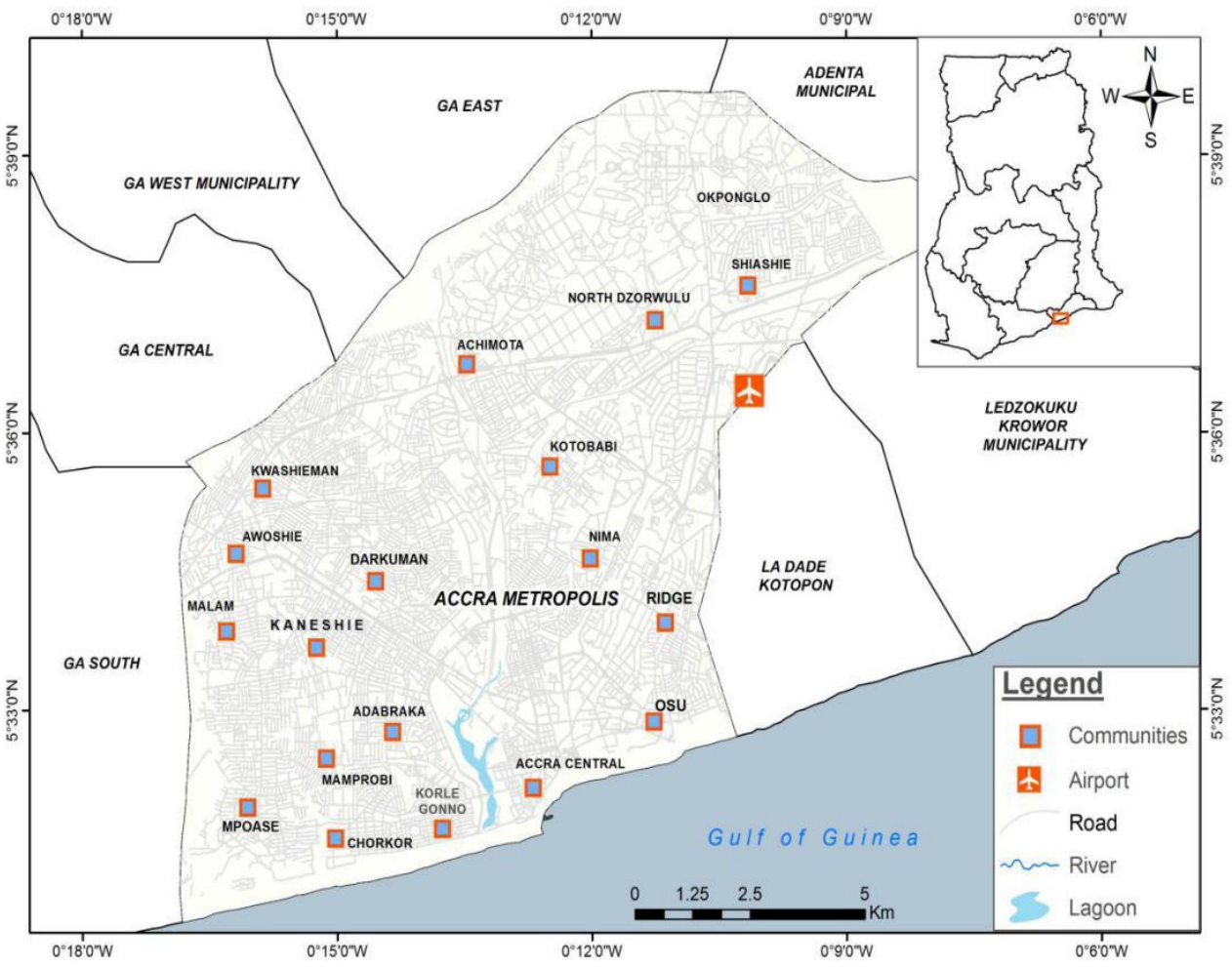

Figure 4. Map of Accra Metropolis (Source: Accra Metropolitan Assembly) 


\subsection{Study Design}

The study design used was purposive sampling survey. This design was chosen because the study involves a systemic collection and presentation of household data to give a clear picture of real situation. It aims at getting information on impediments and constraints of waste management in Accra Metropolis. Key Ministries, Departments, Agencies and individuals who matters in solid waste management were contacted for information. The Officers from Accra Metropolitan Assembly, Zoom Lion waste management company as well as key informants such as assembly men, chiefs, opinion leaders and focused groups were interviewed. Other elements of the sample were women.

Justification for using simple random sampling is it ease of assembling the sample. It is also considered as a fair way of selecting a sample from a given population since every member is given equal opportunities of being selected. Theoretically, the only thing that can compromise its representations could be luck. An unbiased random selection are important in drawing conclusions from the results of a survey as the goals of research is to be able to make conclusions pertaining to sample population. Due to the representativeness of a sample obtained by simple random sampling, it is reasonable to make generalizations from the results of the sample.

\subsection{STUDY POPULATION AND SAMPLING TECHNIQUES}

Target population for the questionnaire survey was women between the ages 20 years and above. This is because they were mostly in charge of sweeping and gathering of all sorts of domestic solid waste in homes and disposing of them. Men were not considered in in the survey because in Ghana domestic waste are mostly handled by women.

\subsubsection{Sample Frame and Sample Size Determination}

A total number of (806875) female population between the age group of 15 and 65 was obtained from Ghana Statistical Service (GSS) for AMA. This represented the sample frame of the questionnaire survey. Furthermore, the mathematical method was used to determine the sample size for the survey. Below is the procedure.

Formula: $\mathbf{n}=$

$$
1+\mathrm{N}(\alpha)^{2}
$$

Where $\mathbf{n}=$ sample size, $\mathbf{N}=$ sample frame (806875)and $\boldsymbol{\alpha}$ represented the margin of error which is $\mathbf{0 . 0 5}$ with confidence level of $\mathbf{9 5 \%}$. By substituting 806875 and 0.08 into the formula: , $\mathbf{n = 3 9 9}$.

Therefore, the sample size for the survey was 399 hundred and ninety nine (399). This was to ensure that the sampled mean was closer to the population mean so as to minimize errors. It is however important to note that the sample size depended on financial resources and the given period of the study. In the light of this, out of the 399 sample size, only 326 respondents participated in the survey.

Table 1 : Communities in Accra Metropolis

\begin{tabular}{cc}
\hline Communities & Estimated population \\
\hline Darkuman & 89245 \\
Mpoase & 66987 \\
Mamprobi & 96788 \\
Chorkor & 64945 \\
Kaneshie & 75615 \\
Accra Central & 63432 \\
Kotobabi & 54789 \\
Osu & 52654 \\
Achimota & 67986 \\
Shiashie & 59642 \\
Adabraka & 81964 \\
Ridge & 48462 \\
Kwashieman & 83792 \\
\hline
\end{tabular}




\begin{tabular}{cc} 
Mallam & 68,267 \\
Nima & 84586 \\
Awoshie & 68583 \\
North Dzorwulu & 75893 \\
Korle Gonno & 64621 \\
\hline
\end{tabular}

Source: Ghana Statistical Service

Table 2: number of sampled population per community

\begin{tabular}{ccc}
\hline Sampled Area & Estimated population & Number of respondents sampled \\
\hline mamprobi & 96788 & 30 \\
Kaneshie & 75615 & 30 \\
Chorkor & 64945 & 30 \\
Korle gonno & 64621 & 30 \\
Darkuman & 89245 & 30 \\
Adabraka & 81964 & 30 \\
Kwashieman & 83792 & 30 \\
Mallam & 68,267 & 30 \\
Rridge & 48462 & 30 \\
Nima & 84586 & 30 \\
Osu & 52654 & 30 \\
Achimota & 67986 & 30 \\
\hline
\end{tabular}

\subsection{Mode of Data Collection}

The following methods were used to obtain relevant information from respondents and key focal persons.

In-Depth Interview: Three hundred and twenty six (326) respondents comprising 250 household woman and 76 traders whose activities leads to waste generation were randomly selected for interview. The survey conducted employed six field assistants to help administer the questionnaires as the coverage area is very large. Purposive sampling was used to randomly select respondents from sampled areas. The relevance of in-depth interview was to find credible feed back from the respondents and other stakeholders in the waste management system.

Key-Informant Interview: This was also used to obtain information from opinion leaders, officials from the Metropolitan Assembly, Assembly men, stakeholders and the waste management company (Zoom Lion). Face-to-face interviews were used to obtain information from the following key stakeholders as far as solid waste management is concerned in the study area.

- Assemblymen in the selected areas

- Accra Metropolitan Assembly (Metropolitan Environmental Officer)

- Waste Management Department (Landfill Manager) and

- Zoom lion Company Limited (regional operations manager).

Data Analysis: After data collection from the field, editing and coding of the questionnaires were than. Data was analysed with Statistical Product and Service Solution (SPSS), version 23 (2015 edition). The results of the data analyses were presented in the form of graphs, charts and tables for clear illustrations.

\section{RESULT AND DISCUSSIONS OF THE RESEARCH}

This chapter entails analysis, results and discussion of the findings from the survey data and key informant interview. The discussions of the analyses were to gives clear insight of the research 
findings. It covers socio-demographic characteristics of the respondents, their views about constraints and factors affecting waste management.

\subsection{Socio-Demographic Characteristics of Respondents}

This section presents the characteristics of the respondents sampled. This is done by analyzing the age of respondents to give clear picture about the respondents' demographic information and how their age affects solid waste management.

\section{Age of respondents}

Age of respondents was taken into concentration to find out whether age affects waste management. Usually people who are old are more responsible as society would condemn any social deviant. In Ghana adult are expected to behave in matured way that up and coming young ones can emulate.

The research revealed most of the people responsible for household waste are the youth. Those living together with their parents have to see to it that waste generated in the house were disposed in a more acceptable way. The study showed that majority of the respondents responsible for waste management in their various homes and work places were the youth between 20 to 39. As part of their duties, they ensure that household waste generated mostly are properly collected and disposed. The elders among the respondents range from 50 -59 and 60 and above. Most of the elders are those not busy or mostly in the house to dispose the household waste on behalf of the family while the rest of the household go to work or engage in daily activities that raise money for the family.

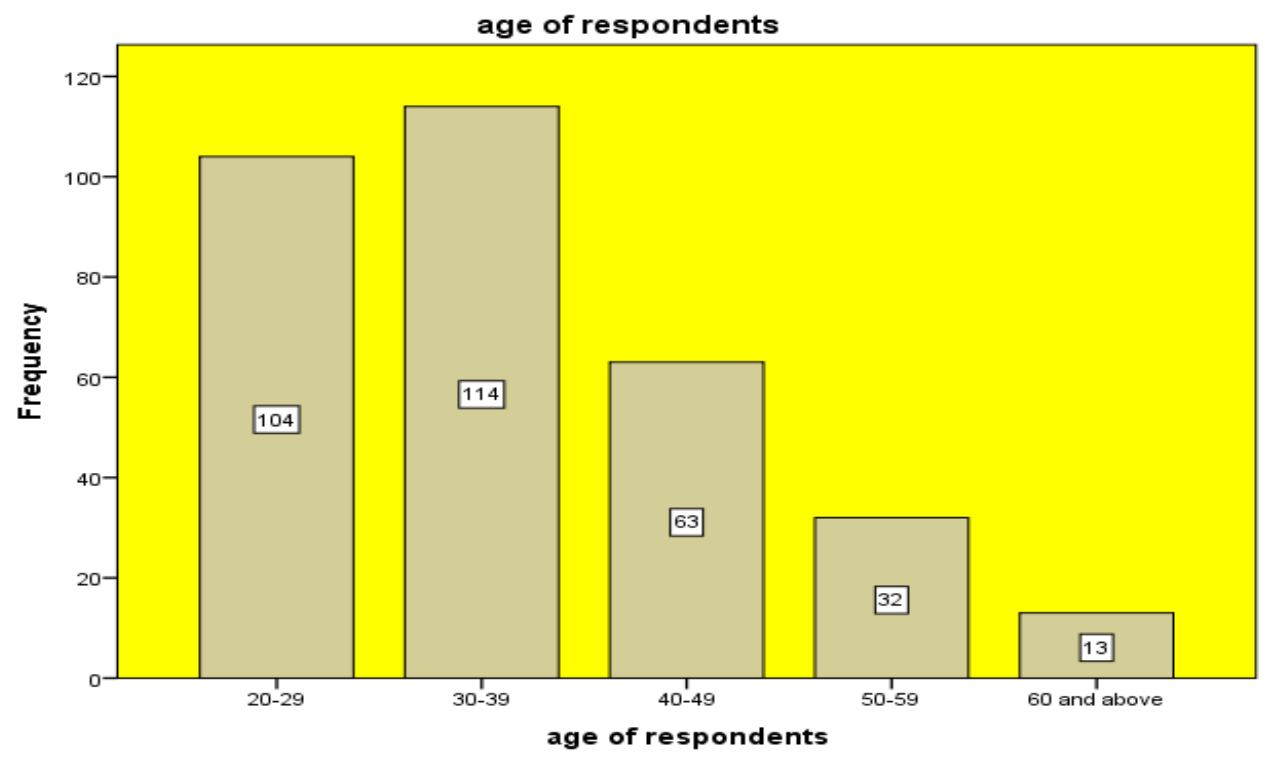

Figure 5 : Age of respondents

\subsection{Types and components of solid waste generated}

Knowledge on types and the components of solid waste generated will inform management to use the appropriate technology and suitable logistics to effectively deal with the various components in solid waste management. Methods such as source separation, recycling, composting can be used depending on the component of waste in the waste stream. Integrated waste management approach which creates opportunities such composting, biogas, recycling, reuse and employment as well as reducing environmental hazards is the best. As a matter of fact about $90 \%$ 
of household waste generated in Accra is dump at landfill sites which also has adverse effect on the environment.

According to Asase (2012) Waste Management Department (WMD) and Zoom Lion Ghana Ltd, estimated that $0.73 \mathrm{~kg}$ per capita waste is generated daily by household in the Metropolis. The average per capita household waste generation obtained for the Accra Metropolitan cities was comparable to the $0.75 \mathrm{~kg} /$ person/day generation rate reported for all metropolitan cities in Ghana by the Ministry of Local Government and Rural Development (MLGRD, 2010) in a forecast of National Environmental Sanitation Strategy and Action Plan (NESSAP) 2010-2015. This amounts to 1552 tonnes of household waste a day. According to the Zoom Lion and WMD, the commonest types of waste generated in the area were food waste, rubbish, and ashes. The research also took sample data of waste from some respondents to compare to actual figures from Accra Metropolitan waste department. Using the following method:

Percentage composition of waste fraction $=$ weight of separated waste $\quad \times 100$ total of mixed waste sampled

This was done to roughly ascertain the average figures that constitute solid waste in the metropolis in various areas within the metropolis with that of figures obtained from AMA. The table below shows average percentage of a component of waste generated daily. This was to compare to the secondary data obtained from the metro waste department. Two set of data was collected at each waste dumping site located within the sampled areas of the respondents. The component was analysed to find the characteristics of domestic waste generated so as to know the fractions of domestic waste that can easily be sorted, recycled or disposed. The research showed that bulk of the waste generated is organic which $60 \%$ is on the total waste generated domestically. Food waste forms bulk of the organic waste and therefore using anaerobic digestion to treat this kind of waste could be environmentally friendly. Organic waste is commonly used in Ghana for composting and it is practiced by few groups and individuals, however only few commercialized projects on composting utilizing MSW are available in Ghana as has been reported by Bensah et al. (2015). Personal data collected from some household at dumping sites showed that averagely $60.8 \%$ of most household waste is organic.

There were similarities in the fractions of the various waste streams although few variations were also seen with some of the fractions. The organic fraction was the highest and compares to the range reported for some developing countries such as 50-74\% in some cities of China by Tai et al (2011) and 51-58\% in India by Ranjith (2012). Plastic and rubber which forms about $9 \%$ of the domestic waste is the major challenge in Ghana. Fobil et al (2006) outlined the different plastic composition in the waste stream of Accra; it's moved from 1.4\% in 1979, 4\% in 1993, 5\% in 1997 to $8 \%$ in 2000 . In this study, the average plastic in the waste stream was $9.8 \%$. This is lower than the 20\% plastic reported by Puopiel (2010) in Tamale and 16\% in Aburi in the Eastern Region (AsamoahOkyere, 2011) and Tarkwa in Western Region (Ansah, 2014). Plastic recycling has not received the needed attention; it is believed that less than $2 \%$ of plastics are recycled in Ghana; the rest form major pollutants in public places and environmental receptacles in Ghana Most open drains and gutter are chocked with plastics and rubbers preventing water flow which leads to flooding in Accra during rainy season. These rubbers and plastics can be recycled to produce raw materials for industries instead of allowing it to pollute the environment. The study also showed that paper and cardboard represent $7 \%$ of household waste generated daily. Paper recycling has not been initiated 
on a larger scale, though few individuals have been recycling smaller portion as sanitary tissues (Osei-Mensah, 2014).This implies that when integrated waste management system is adopt, papers and cardboard could easily be separated and recycled for for other alternative uses.Also this can also generated employments as people can sort waste and sell the recyclable material for money. The data collected showed that metals, textiles, glass and inert represents $3 \%, 2 \%, 2 \%$ and $2 \%$ respectively of domestic waste generated daily which fall within the range of some $1 \%$ and $3 \%$ of fraction of metals, glass and textiles determined by Ansah (2014) which compares with other studies. Scrap metal is one fraction of MSW that has a great market in Ghana and beyond. This reason makes them attractive to scrap collectors and itinerant buyers therefore reducing their composition in the waste stream to about $2 \%$. They are utilized in local steel industries and are even exported. Metal scraps collection now serves as source of employment for some of the youth who move door to door to buy scrap metals in homes. According to UNEP (2013), apart from percentage component of waste generated daily which is easily determined, waste generation rates across Ghana irrespective of the socioeconomic considerations ranged from 0.2 to $0.8 \mathrm{~kg} /$ person/day. However, higher generation rates have been reported for OECD countries, $1.39 \mathrm{~kg} /$ person/day (OECD, 2010).

Table 3: Types and Components of Solid Waste Generated.

\begin{tabular}{|c|c|c|c|c|c|c|c|c|c|c|c|c|c|c|c|c|}
\hline \multirow{3}{*}{$\begin{array}{l}\text { Sampled area } \\
\text { Darkuman } \\
\end{array}$} & \multicolumn{16}{|c|}{ Components of household solid waste daily } \\
\hline & \multicolumn{2}{|c|}{ organic } & \multicolumn{2}{|c|}{ metals } & \multicolumn{2}{|c|}{$\begin{array}{l}\text { Plastic } \\
\text { and } \\
\text { rubber }\end{array}$} & \multicolumn{2}{|c|}{$\begin{array}{l}\text { Paper and } \\
\text { cardboard }\end{array}$} & \multicolumn{2}{|c|}{ Textiles } & \multicolumn{2}{|c|}{ glass } & \multicolumn{2}{|c|}{$\begin{array}{l}\text { miscellaneo } \\
\text { us }\end{array}$} & \multicolumn{2}{|c|}{ inert } \\
\hline & 60 & 61 & 3 & 2 & 9 & 10 & 7 & 8 & 2 & 3 & 2 & 2 & 11 & 12 & 2 & 3 \\
\hline Mambrobi & 61 & 62 & 2 & 3 & 7 & 9 & 8 & 7 & 3 & 2 & 1 & 3 & 10 & 11 & 2 & 2 \\
\hline Korle Gonno & 62 & 61 & 3 & 3 & 8 & 9 & 7 & 7 & 3 & 2 & 2 & 3 & 11 & 13 & 2 & 2 \\
\hline Chorkor & 61 & 60 & 2 & 3 & 9 & 8 & 6 & 8 & 2 & 1 & 2 & 1 & 10 & 11 & 2 & 3 \\
\hline Mallam & 60 & 62 & 2 & 2 & 8 & 7 & 7 & 7 & 3 & 2 & 3 & 2 & 10 & 10 & 3 & 2 \\
\hline Aworshie & 63 & 60 & 3 & 1 & 7 & 9 & 8 & 7 & 3 & 2 & 2 & 3 & 11 & 10 & 3 & 1 \\
\hline Kwashieman & 60 & 59 & 2 & 1 & 10 & 8 & 8 & 8 & 2 & 2 & 2 & 3 & 11 & 11 & 3 & 2 \\
\hline Central Accra & 60 & 60 & 2 & 2 & 7 & 9 & 6 & 8 & 3 & 2 & 1 & 2 & 10 & 9 & 4 & 3 \\
\hline Mpoase & 62 & 61 & 2 & 3 & 9 & 8 & 7 & 7 & 2 & 2 & 2 & 2 & 11 & 10 & 2 & 2 \\
\hline Osu & 62 & 60 & 2 & 3 & 9 & 9 & 10 & 9 & 2 & 3 & 2 & 3 & 12 & 11 & 3 & 2 \\
\hline Shiashie & 61 & 62 & 3 & 2 & 10 & 11 & 11 & 11 & 2 & 3 & 2 & 2 & 10 & 11 & 2 & 2 \\
\hline $\begin{array}{l}\text { North } \\
\text { Dzorwulu }\end{array}$ & 62 & 60 & 2 & 2 & 9 & 10 & 10 & 12 & 3 & 3 & 2 & 3 & 10 & 10 & 2 & 3 \\
\hline Kotobabi & 63 & 61 & 2 & 3 & 11 & 9 & 11 & 10 & 2 & 2 & 3 & 2 & 11 & 10 & 2 & 2 \\
\hline Ridge & 61 & 62 & 3 & 2 & 11 & 10 & 10 & 11 & 2 & 3 & 2 & 2 & 12 & 9 & 2 & 3 \\
\hline Nima & 61 & 60 & 1 & 3 & 10 & 10 & 12 & 11 & 3 & 2 & 2 & 3 & 10 & 12 & 1 & 3 \\
\hline Adabraka & 60 & 60 & 2 & 3 & 10 & 11 & 12 & 11 & 2 & 3 & 1 & 3 & 10 & 11 & 2 & 2 \\
\hline Achimota & 59 & 61 & 2 & 2 & 12 & 10 & 11 & 10 & 3 & 2 & 4 & 2 & 12 & 9 & 2 & 3 \\
\hline Kaneshie & 61 & 62 & 3 & 2 & 13 & 10 & 10 & 11 & 2 & 2 & 2 & 3 & 11 & 11 & 2 & 1 \\
\hline Average total & 58 & 60.8 & 2.2 & 2.4 & 9.6 & 9.8 & 9.1 & 9.3 & 2.3 & 2.3 & 2.2 & 2.4 & 10.7 & 10.6 & 2.4 & 2.3 \\
\hline
\end{tabular}

Source: 2015 data collected from dumping and skip containers site 
Table 4 : Types and Components of Solid Waste Generated

\begin{tabular}{cc}
\hline Components of waste & Percentage generated daily \\
\hline organic & 60 \\
metals & 3 \\
Plastics and rubber & 9 \\
Paper and cardboard & 7 \\
Textiles & 2 \\
glass & 2 \\
Miscellaneous & 11 \\
inert & 2 \\
\hline
\end{tabular}

Source: Accra Metropolitan Assembly.

\subsection{Methods of disposal of household solid waste}

The disposal of household solid waste is one of the functional elements in the management of waste. Waste can be manage efficiently if the stakeholders as well as mechanisms put in place to manage waste work effectively in integrated manner. Waste generation in sub-Saharan Africa is approximately 62 million tonnes per year. Per capita waste generation is generally low in this region compared to annual waste generation in East Asia and the Pacific Region which is approximately 270 million tonnes per year (UN-Habitat, 2009). This implies that waste generation in Africa is not above the threshold of waste management capacity levels in most big cities in Africa. A study carried by Momoh and Oladebeye (2010) showed that, the methods of solid waste disposal include dumping of waste in gutters, drains, by roadside, unauthorized dumping sites and stream channels during raining season and burning of wastes on unapproved dumping sites during the dry season. This has gone to confirm that the practices of solid waste disposal in the 1950s still exist today and study area is not an exception. This implies that indiscriminate waste disposal has been a challenge for long time. Table 5 below illustrates the various ways of solid waste disposal by respondents in AMA. The survey conducted revealed that all the respondents have different reasons which encourage them to dispose solid waste in the manner they do. According to the survey, 39 of the respondents representing $12 \%$ burn their waste on their compounds or any open space in their houses. Most of them are of the view that, burning their waste as means of disposal is cheap, saves time and also does not have much effect on the environment as most burning take place at night or early morning when neighbors are not awake to inhale smoke or any bad odor the burning might generate. The research also indicated that 53 of the respondents representing 16.3\% dispose their waste by burying them in their compounds. These respondents mostly dig big trenches on their piece of land and dispose their household waste in these trenches until they become full and bury it with sand. Most of this methods occur in places where household have large reserve land on their compounds which they have no immediate intention of developing that portion of land. The size of the trenches depends on the volume of waste generated by the household per day and availability of land. The respondents think this is the best method to handle waste since their houses are far from the skip site and also the private waste collectors they engage are not mostly reliable. Some of these private waste collectors charge exorbitant amount before they carry the waste, hence most of them see it quiet expensive. Dumping at communal dump site also represent 14 respondents which also makes $4.3 \%$ of the total respondents. Due to environmental hazards solid waste generates in the Metropolis especially during rainy season causing flood in the flood prone areas, the government discourages this system of waste disposal in the country. Moreover, due to population explosion in the metropolis generating land 
scarcity, most communities who use to reserve portion of community land for waste dumping have stop that. The respondents who dump their waste by this means live in the suburb of the Metropolis where they have no place for dumping their waste so the community earmarked portions of community land for disposal. This is mostly done when the chiefs and the custodians of the land agree to devote portion of stool or communal lands for waste dump site.

The research also showed that 128 respondents representing 39.3\%of the total respondents dump their waste at skip container sites. Though some of them are faced with challenges of distance to skip container site or high rate charged by the skip caretakers, they have no option than to cope. Most of them pile the waste in polythene sucks, dustbins or big polythene bag till it get full before they send it to the skip containers site. Some of them confessed that at times they are tempted to dump the waste in opens drains during rainy season if they cannot send it to the skip container sites due to distance and the bad occur of the waste. From the survey, it was also realized that 92 of the respondents representing $28.2 \%$ indicated that, private waste collectors come to their homes to collect their waste. The main private waste management company in Ghana (Zoom Lion) has the services of door to door waste collection. The waste collectors moves with tricycle or big tracks with compactors and collect waste in areas with good road network. Some of the residents pay monthly or weekly depending on the agreement with the waste management company. Furthermore there are other private individuals who have also created employment from waste disposal. They have their own means of transport and move to houses and collect their waste. Though their services are expensive compared to Zoom Lion Company, most residents think their work is efficient and reliable. The system of paying fees for waste removal or disposal works well and represents sound practice when individuals want to get rid of their waste and can afford the fees. It works poorly when people are too poor to pay fees, when the fees are simply too high, or when there are ready alternatives and no controls for disposing of wastes, such as by throwing them into the countryside (Kodwo, 2012)

Table 5: Methods of disposal of household solid waste

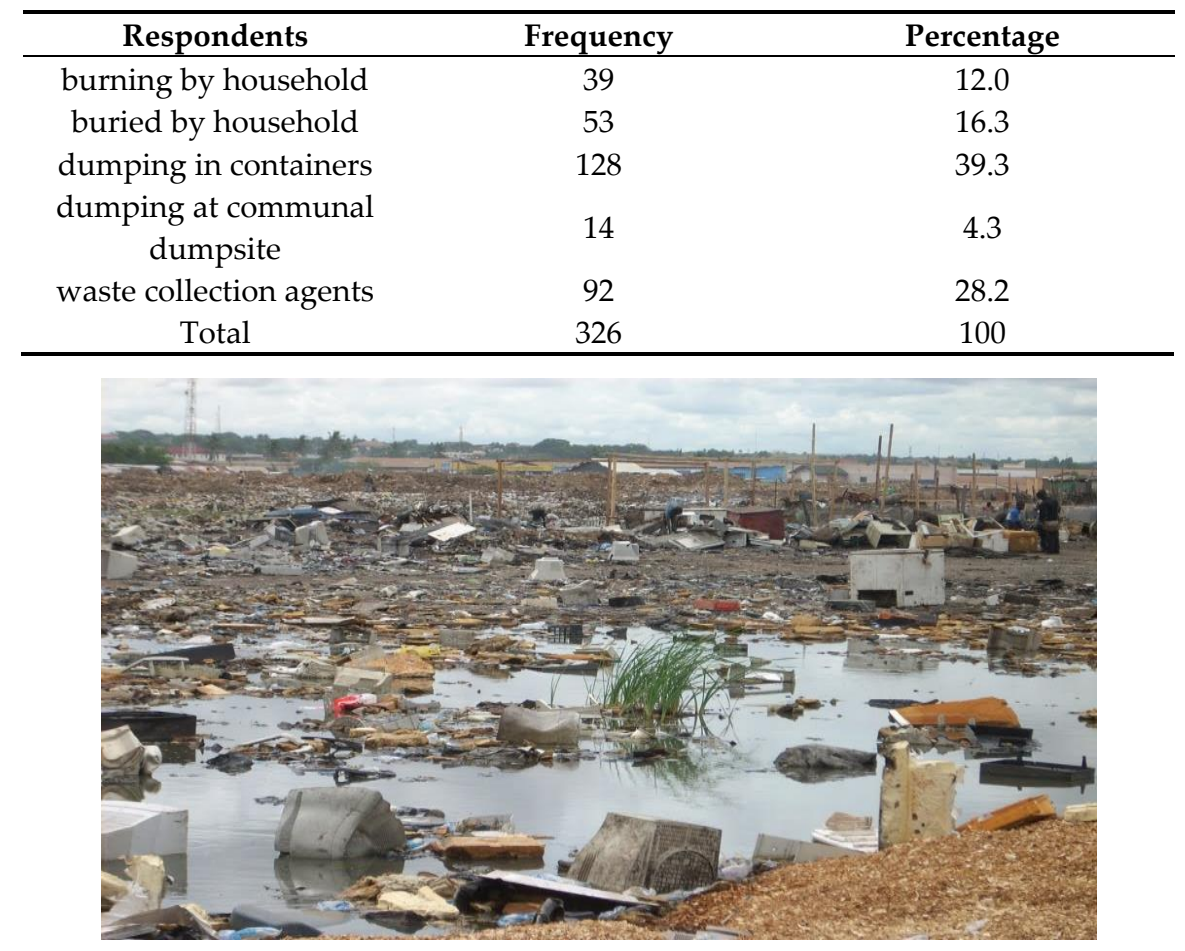

Figure 6.Picture of communal waste dumping site 


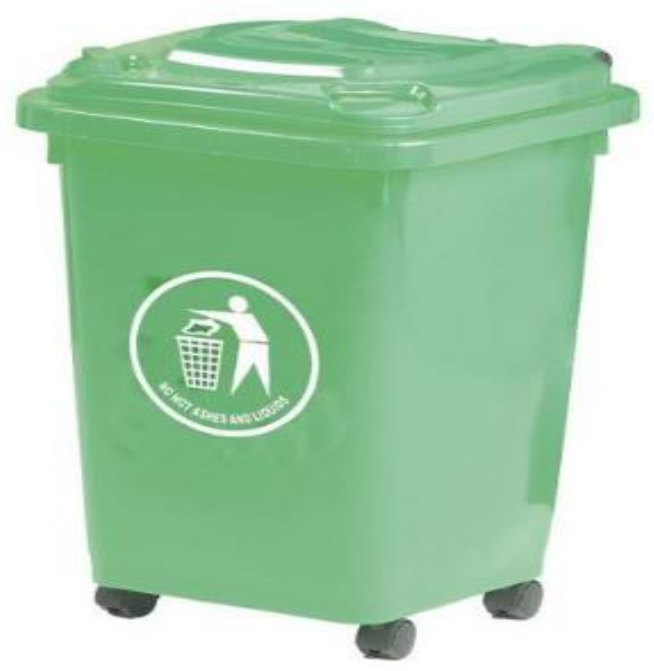

Figure7.Household waste collection containers

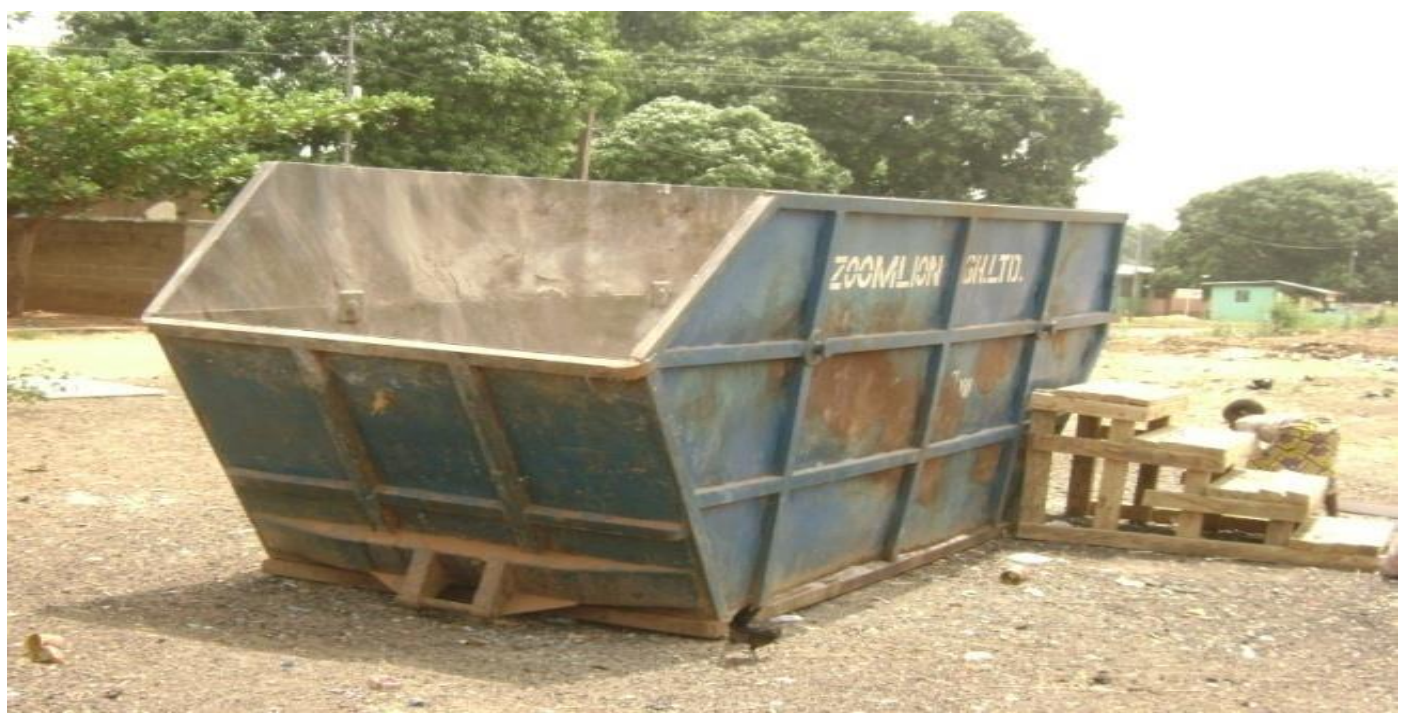

Figure 8.Public solid waste dumping container

\subsection{Availability of skips and dustbins for waste storage}

The urban poor living in slums in Accra are vulnerable to public health impacts of improper waste management. The poor always tend to be the most adversely affected by environmental hazards due to improper waste management, poor access to health services to get treatment and poor means to avoid everyday proximity to waste management related problems (UNSD,2009). This situation is prevalent in Accra too. High income households who can buy door-to-door waste collection services get a special plastic bin for waste, but low income communities have to use large skip containers. Various studies comparing these two methods of waste collection found that the door-to-door plastic bin system had a higher quality service as opposed to the low quality service at skip site.

There have been numerous attempts to solve this problem of service delivery to Accra's low income communities. AMA and Zoom lion are undertaking a project to provide plastic containers for waste collection to individual households for free. The freely distributed plastic containers were being used for water storage or other alternative uses as opposed to waste collection. To discourage 
such alternative uses like water storage, the authorities provided free metal wire containers, which were later stolen or sold as metal for money.

An interview with the Assemblymen in the twelve (20) selected areas revealed that lack of skips and dustbins was major problem in the Metropolis. Zoom Lion Ghana Ltd. which was the main private company in charge of waste collection has been unable to supply skips and dustbins to areas they served. The Accra Metropolitan Accra (AMA) in collaboration with other donor partners distributed new dustbins to various households in the Metropolis but most household use the new dustbins to store water and other household items. Some household also over fill their dustbins with waste which easily break the wheels of the dustbin when pushing it to the skip site or when trucks empty the bins. Table below shows the selected areas, estimated population, number of dustbins and skips available as well as the number required for storing waste.

Personal interview with the AMA waste management department indicated that the funds allocated to sanitation and waste management is woefully inadequate. This affects distribution of skip containers and household dustbins. According to the AMA and they use their own internally generated funds (IGF) to manage waste as Government funds does not come timely and is also not enough to run the activities of the Metropolis not alone manage waste. Discussions with the private waste management company (zoom Lion) indicated that government funds received for operations are not enough preventing them to manage the waste effectively. Due to inadequate funds maintenance and operations cost mostly affects their capacity.

Table 6: Distribution of Dustbins and Skips in Study Area

\begin{tabular}{cccccc}
\hline Communities & $\begin{array}{c}\text { Estimated } \\
\text { population }\end{array}$ & $\begin{array}{c}\text { Number of } \\
\text { dustbins } \\
\text { available }\end{array}$ & $\begin{array}{c}\text { Estimated } \\
\text { Number of } \\
\text { dustbins } \\
\text { required }\end{array}$ & $\begin{array}{c}\text { Number of skips } \\
\text { available }\end{array}$ & $\begin{array}{c}\text { Estimated Number } \\
\text { required }\end{array}$ \\
\hline Darkuman & 89245 & 5451 & 9500 & 14 & 30 \\
Mpoase & 66987 & 1671 & 2400 & 16 & 25 \\
Mambrobi & 96788 & 3561 & 12000 & 18 & 35 \\
Chorkor & 64945 & 951 & 2300 & 14 & 20 \\
Kaneshie & 75615 & 2691 & 3450 & 11 & 25 \\
Accra Central & 63432 & 1541 & 4500 & 23 & 40 \\
Kotobabi & 54789 & 893 & 2400 & 13 & 30 \\
Osu & 52654 & 1032 & 6000 & 12 & 25 \\
Achimota & 67986 & 1572 & 5600 & 15 & 30 \\
Shiashie & 59642 & 1261 & 5200 & 19 & 25 \\
Adabraka & 81964 & 983 & 7300 & 12 & 25 \\
Ridge & 48462 & 456 & 900 & 19 & 20 \\
Kwashieman & 83792 & 574 & 800 & 14 & 30 \\
Mallam & 68,267 & 393 & 5000 & 16 & 25 \\
Nima & 84586 & 689 & 3000 & 13 & 30 \\
Awoshie & 68583 & 700 & 2000 & 17 & 25 \\
North Dzorwulu & 75893 & 940 & 4000 & & 25 \\
Korle Gonno & 64621 & & & 14 & \\
\hline
\end{tabular}

Source: Accra Metropolitan Assembly, April, 2015

\subsection{Time spent to dispose of waste in skip}

Time spend to dispose of waste is very crucial for efficient waste management. Moving long distance to dispose waste at dumping or container site can be frustrating and discouraging especially if the waste produces bad odor (Adjei, 2013). Respondents time spent to dispose of waste 
realize in the course of the research. The survey showed that majority of the respondents representing $36.50 \%$ travel above 25 minutes to dispose their waste at the skip site or authorized places. Interview and discussion with the respondents showed that most of the household who are far from the dumping sites find their own alternative means of disposing their waste. Either they engage and pay people to come and convey it to the dumping site or they dig big trenches in their homes if there is available land. Others also said they burn theirs in situations where they cannot send it far to dispose them. $26.99 \%$ and $16 \%$ of the respondents travel $21-25$ minutes and $16-20$ minutes respectively to dispose their waste. These respondents are of the opinion that most households and individuals dump their waste at unapproved places or in gutter because of the distance they cover before disposing their waste. The survey indicated that only $7.67 \%$ of the respondents move for less than 10 minutes to dispose their waste. They are able to dispose their waste regularly at dumping sites dues to proximity of their houses to the site. They said is good to have skip containers near houses so that people can easily dump their waste should the need arise. Nearness of dumping site or skip containers near residence encourages people to dispose their solid waste in an acceptable manner.

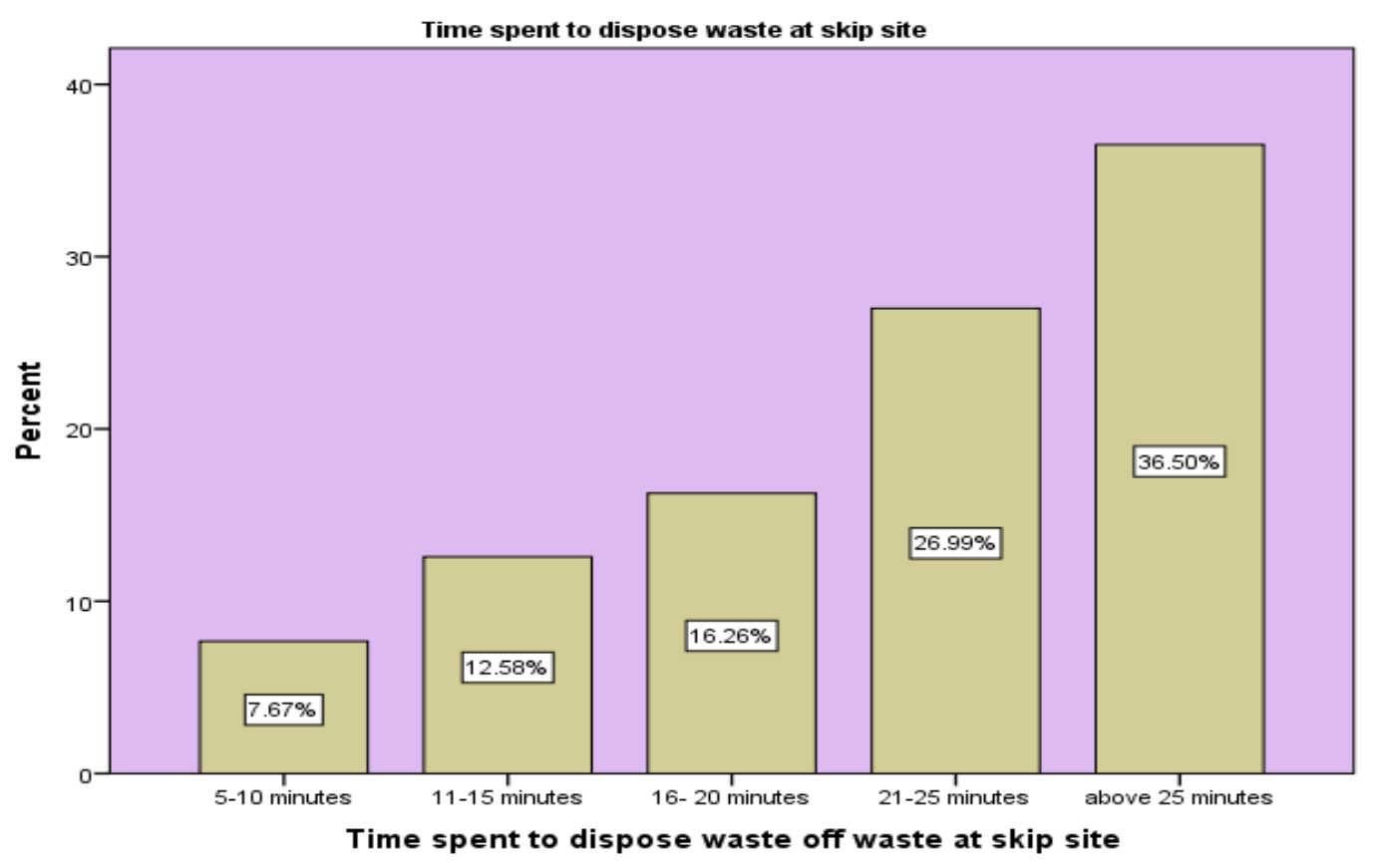

Figure 9. Time spent to dispose waste at skip site

\subsection{Regularity of waste collection}

Regular collection is an important exercise in solid waste management. The survey conducted showed number of waste collection on weekly bases. The figure above showed that $42 \%$ of the respondents get the trucks to come and empty their dust bins once a while. The trucks do not come on regular bases as they supposed to. These create a lot of problems when the bust bins are full hence generate bad stench.The study indicated that $22.1 \%$ of the respondents empty their bins once a week. This also poses a lot of threat to households who generate more waste on daily bases. The respondents who get their bins emptied everyday are those is the residential areas who give tips to most of the waste collectors thereby encouraging them to always come to their homes regularly. The key informant interview showed that most of the houses that get their dust bins emptied every day or on 
regular bases are either close to main roads, tip waste collectors or engage private individuals who pick their waste and dump them at skip sites. Personal observation in the study area showed that households whose houses do not have access to good roads have problems with waste collectors who are supposed to empty their dust bins on regular bases.

Interview with skip site care takers revealed that most of the skip containers are not also picked regularly and this makes some of the containers get full to the brim. Some of the waste falls out when people continue dumping waste in filled containers. Personal observation revealed that most skip sites that do not get regular service for that matter there are huge pile of waste at some skip sites.

\section{Waste collection frequency}

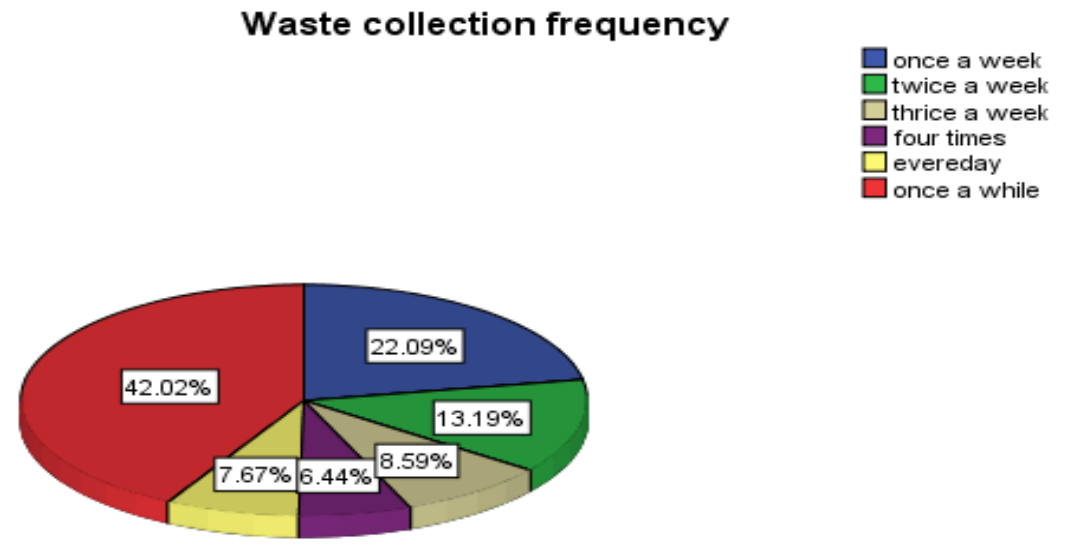

Figure 10. Waste collection frequency

\subsection{Types of constraints affecting waste management.}

Waste management comes with a lot of constraints that poses threat to most waste management companies and even the most developed countries also face constraints from the waste management sector. Figure 11 below shows the main constraints affecting waste management in Ghana. The research conducted showed that each constraint has no correlation with any other constraints.

The research conducted indicated that as a result of current economic challenges, the government does not provide enough funds timely for the waste management companies in the Metropolis to discharge their duties efficiently. As a result, the city is engulfing with filth and outbreak of cholera and malaria is rampant. Adequate funds which enhance efficient waste collection, disposal and recycling is comes from funds government generates from taxes. This implies that, any country facing economics challenges would not generate enough funds locally so as to make good allocations to the waste management sector. As a matter of fact, government fund waste management because if left in the hands of private organisations, though efficiency can be achieve to some extent, the cost of services that would be transferred to citizens to pay may be quiet erroneous that the poor and the lower income level citizens forming majority of the entire population would devise crude ways of waste disposal which could be the detrimental to the whole nation. The rationale for efficient waste management is that there are benefits to all members of society for having the overall solid waste management system in place (Ghana Audit Service, 2011). Survey showed that $28.92 \%$ of opinion letters and focus group discussion indicated economics constraints are the main predicament of poor waste management in Accra Metropolis. The study also showed that $21.85 \%$ of the respondents made of opinion leaders believed that social constraints is one of the main constraints that hinder efficient waste management in the Metropolis. Batool (2009) explained that in developed or developing countries, there are social or cultural norms accepted by the society and 
there are other norms that society does not conform with. According to him, such norms affect designs of solid waste management systems which mostly help in achieving efficient results. Where the society allows only a certain social class or group to deal with solid waste, the availability of work force for solid waste collection and disposal becomes constrained and hence inefficiency of waste management is likely to set in.

In most developing countries, there is lack of human resources at both the national and local levels with technical expertise necessary for solid waste management planning and operation (Ngoc, 2009). Many officers in charge of solid waste management, particularly at the local level, have little or no technical background or training in waste management. Without adequately trained personnel, a project initiated by external consultants could not be continued. Therefore, the development of human resources in the recipient country of external support is essential for the sustainability of the collaborative project. The focus group discussion involving major stake holders among Zoom Lion waste management company, Metro Environmental management officers, Environmental Protection and other government agency indicated that most of the officers in change of waste management have no requisite skills. Though most are highly educated, their area of specialization is not waste management. Another technical constraint in developing countries is the lack of overall plans for solid waste management at the local and national levels. As a result, a solid waste technology is often selected without due consideration to its appropriateness in the overall solid waste management system.

Poor technical services due to lack of expertise can affect the design of efficient waste management systems for rapid result.. In such a case, the low collection coverage is a bottleneck in the overall solid waste management system in the city, and it would be most cost-effective to provide resources to upgrade the collection service. The research showed that $17.5 \%$ of the respondents were of the opinion that poor waste management in the Accra Metropolis is due to technical constraints. According to the respondents from the focus group discussion, technically, the Metropolis lack the capacity to manage the volumes of waste generated daily. Lack of environmental engineers who supposed to coordinate, supervise and also draw effective waste management programs pose serious technical constraints in the Metropolis.

Furthermore, institutional constraints were also seen as one of the serious threat to waste management. Due to poor economic challenges, the government do no release funds timely for MMDAS in Ghana to enable them discharge their core mandate of wish waste manage is one .The survey showed that $21.23 \%$ of the respondents believe due to financial constraints the Metropolis in collaboration with the private waste management companies cannot invest adequately in areas such as equipment maintenance, adequate staff and fuel to collect and discharge waste timely as it supposed to be. Institutions which supposed to coordinate activities of other stakeholders to manage waste effectively is lacking in the Metropolis. The study showed that $10.46 \%$ of the respondents also think institutional constraints are challenges. The two major institutions which are responsible for waste management are Zoom Lion Waste Management Company and AMA waste management department. The volumes of waste generated are far beyond the capacity of Zoom Lion and the Metropolitan Waste Department. This always creates problems mostly at disposal site. Most skip containers get full quickly and if not collected, residents dump the waste near the skip sites mostly midnight when the care takers of the skip containers are not around to prevent them. 


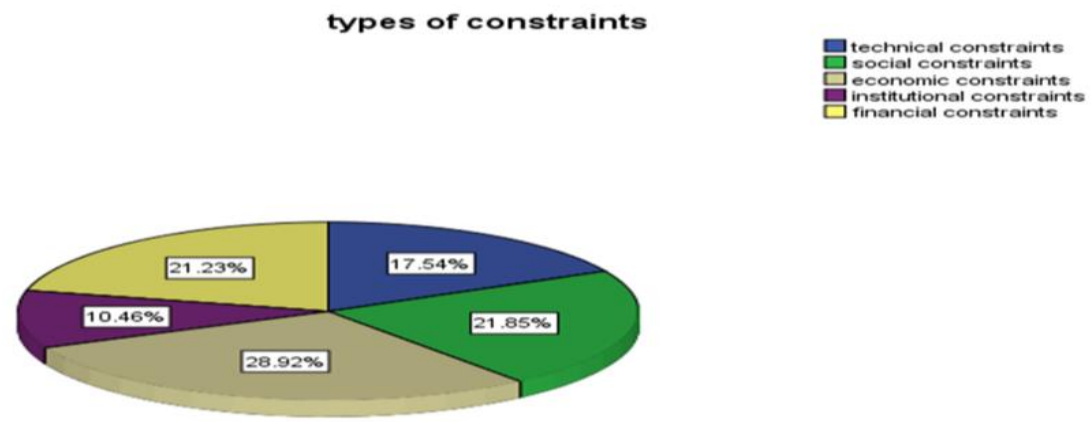

Figure 11: Types of constraints

\subsection{Factors affecting waste management}

Waste management is a big task in every country because it could be nuisance or generate negative consequences if not properly manage. There is several factors that hinder proper waste management. The research conducted showed that there are a lot of factors preventing the government and the waste management companies from properly managing solid waste in Accra Metropolis. The research indicated that the main challenge in waste management is poor public attitude towards waste management. The survey showed that $30.4 \%$ of the respondents from key informant interview attested to the fact that the public attitude to waste management is very appalling. They claim most citizens keep waste in their homes and dump them in open drains during heavy rains. Some of them also keep waste in their homes and dump them at unauthorized places especially midnight and early morning when are asleep. Interview with waste management officers revealed that the Metropolitan Authority in collaboration with the main waste management company in Ghana (Zoom Lion) distributed free dustbins to about $80 \%$ households so as to collect and properly keep domestic waste until the waste disposing tracks comes to collect them finally for disposal but unfortunately most of this households are using the bins to store their personal items. Some even use it to store water for drinking and food items because they claim it is new for waste storage. The research also showed that 82 respondents representing 25.2\% indicated that poor enforcement of sanitation bye laws in the metropolis is encourages citizens to dump refuse anywhere or any how. The AMA has not fully enforced it sanitation bye laws to punish people whose activities poses environmental threat to the entire metropolis. In Ghana particularly Accra, people defecate in polythene bags and dump them in gutters and other open places due to lack of toilet facilities in most houses especially in slum areas. Most residents along the coast use the beaches as place of convenient since they lack toilet in their homes. During rainy seasons people dump their waste in running waters and open drainage system which all end up at the Korle Gonno lagoon and the Sea. Most gutters in Accra are chocked with solid waste mostly domestic ones due to poor enforcement of bye laws by AMA. The Accra Metropolitan Assembly (AMA), Environmental Protection Agency and other stakeholders mostly engage contractors to drain majors storm drains filled with waste in the metropolis but due to poor attitude towards waste management. However lack of law enforcement to punish those who dispose waste was at undesignated places have led to major gutters and storm strains continuously chocked with solid waste. The consequences of these are flood, cholera and malaria in the metropolis.

Inadequate and untimely release of funds by government was also seen has one of the main challenges of waste management in the metropolis and Ghana as a whole. Due to economic crises, 
the government does not release funds on time to the MMDAS to tackle their annual activities of which waste management is a major component of their action plan (Osei-Mensah et al 2014). The government allocations to waste management are woefully inadequate. The study showed that 69 respondents representing $21.2 \%$ are of the view that inadequate and untimely release of funds leads to poor performance of the waste management companies and the metro waste management department. Poor maintenance and replacement of obsolete tools for waste management pose health hazards to those who come into direct contact with the waste during disposing of the waste. Most of the big trucks are not efficient in disposing the waste because they do not have enough fuel allocation to visit their approved skip collection site the numbers of times they are supposed to. Hence there are more back-locks of waste in most places creating filth and nuisance. The tricycles used by most of the waste officials who go door to door to collect waste in small quantities are broken down compelling residents to travel far distance to dispose waste in skip containers.

The study showed that $3.1 \%$ of the respondents think loopholes in waste management strategies are one of the main factor that hinder proper waste management in the Metropolis. The loop holes are as a result of check and balance is the waste management system. Some of the skip care takers collect money from the waste disposers but do not give proper account to the waste management company. Also the skip loader drivers mostly go to areas where they get bribe from the skip care takers than leaving others areas he supposed to collect and dispose of their waste. Most of the door to door waste collectors also take bribe from some household and dispose their waste regularly when he supposed to follow the routine schedule so as to covers all the designated area assigned to him. Low waste management technology was also seen as one of the main of the challenging serving as bottle necks in the entire waste management process. As GDP/c goes up, it is expected that by 2050 the demand for agricultural goods will rise by $70 \%$ and the demand for meat and other meet products will double. Besides the serious issues related to food production and sustainability, other challenges such as E waste and metallic objects could pose serious threat to waste management though researchers are coming out with best means of recycling and waste disposal. The organic fraction of waste would continuously dominant MSW because food consumption cannot be reduced even if the world faces crises (UNEP, 2013). Apparently there is the need to improve technology that will harness organic waste into compost and other useful by- products rather than indiscriminate disposing. Though $60 \%$ of household waste are organic materials mostly kitchen waste and plants, they are not converted to compost to supply farmers with organic manure. About $90 \%$ of waste generated in Accra is dump in landfill sites which is mostly located at suburbs of Accra. Only $10 \%$ are recycled at the recycle plants recently built by Zoom Lion Company. Nevertheless, only about $7 \%$ of the daily household generated is polythene bags and plastics but due to poor technology of the waste manage company most of the plastics and polythene are dump at the landfill sites which also pose threat to the environment as they do not decompose. Some of these polythene bags litter the environment as well as chocking gutters. The survey indicated that 37 respondents representing $11.3 \%$ are of the opinion that poor waste management technology is the main issue bedeviling effective waste management in Ghana for that matter Accra. They are of the view that if technology is improved, waste especially polythene and other organic materials be recycled to feed the agric sector as well as industries who use polythene as their raw material for production. Poor education and ignorance represented $8.9 \%$ of the respondents view. Key informants interview showed that most people in the metropolis do not care much about adverse effect of waste to the environment. They perceive waste 
management as government obligation no matter how it is disposed by households or industries. Due to poor education and ignorance most residents dump refuse indiscriminately forgetting that during raining season these waste block major storm drains causing floods in Accra and its environs. As a result of filth engulfed Accra, outbreak of cholera and malaria is rampant in Accra.

Table7: factors affecting waste management

\begin{tabular}{|c|c|c|}
\hline Factors & Frequency & percentage \\
\hline $\begin{array}{c}\text { Low waste management } \\
\text { technology }\end{array}$ & 37 & 11.3 \\
\hline $\begin{array}{l}\text { Inadequate and untimely release } \\
\text { of government funds }\end{array}$ & 69 & 21.2 \\
\hline $\begin{array}{c}\text { Loopholes in waste management } \\
\text { strategies }\end{array}$ & 10 & 3.1 \\
\hline $\begin{array}{l}\text { Poor public attitude towards } \\
\text { waste management }\end{array}$ & 99 & 30.4 \\
\hline $\begin{array}{c}\text { Poor education and Ignorance } \\
\text { among Citizens }\end{array}$ & 29 & 8.9 \\
\hline $\begin{array}{c}\text { Poor enforcement of sanitation by } \\
\text { Laws }\end{array}$ & 82 & 25.1 \\
\hline Total & 326 & 100 \\
\hline
\end{tabular}

\subsection{Determinant of correlations between constraints and factors affecting waste management}

Correlation among variables which help to determine an outcome of a research is worth determined so as to know the multicollinearity level between the variables under study and to know which decision to make in relation to the objectives of the research. Figure 8 below shows correlations between factors affecting waste management and the constraints of waste management. The figure indicated that there is no strong correlation between factors and constraints of waste management. The weak correlations among the variables shows each variable is independent on its own hence affects waste management without necessarily relying on other variables to trigger it. The research also showed more correlation among some variables is significant at 0.05 levels than correlations at significant level of 0.01 levels. This implies that constrains such as technical, economic, institutional and social and financial are not necessarily the cause of the factors affecting waste management though there is some level of link to some extent. For instance it is apparent to note that financial constraints directly have effect on inadequate and untimely release of funds for waste management but have no direct relationship with poor attitude towards waste management. Similarly, social constraints have impact on poor education and ignorance among citizens but do not directly correlate to loop holes in waste management strategies. 
Table 8: Correlation between constraints and factors affecting waste management.

\begin{tabular}{|c|c|c|c|c|c|c|c|c|}
\hline \multicolumn{9}{|c|}{ Correlations } \\
\hline & & $\begin{array}{l}\text { types of } \\
\text { constraints }\end{array}$ & $\begin{array}{l}\text { Huge Gap } \\
\text { between } \\
\text { Research } \\
\text { And Policy } \\
\text { Development }\end{array}$ & $\begin{array}{c}\text { Low } \\
\text { involvement } \\
\text { of } \\
\text { entrepreneur } \\
\text { s waste } \\
\text { management }\end{array}$ & $\begin{array}{l}\text { poor public } \\
\text { attitude } \\
\text { towards } \\
\text { waste }\end{array}$ & $\begin{array}{l}\text { Poverty and } \\
\text { Ignorance } \\
\text { among } \\
\text { Citizens }\end{array}$ & $\begin{array}{l}\text { Waste } \\
\text { collection per } \\
\text { week }\end{array}$ & $\begin{array}{c}\text { Non- } \\
\text { regulation of } \\
\text { waste } \\
\text { management } \\
\text { companies }\end{array}$ \\
\hline \multirow[t]{3}{*}{ types of constraints } & Pearson Correlation & 1 & .052 & -.066 & .091 & .012 & -.027 & -.100 \\
\hline & Sig. (2-tailed) & & .345 & .232 & .100 & .825 & .627 & .070 \\
\hline & $\mathrm{N}$ & 326 & 326 & 326 & 326 & 326 & 326 & 326 \\
\hline \multirow{3}{*}{$\begin{array}{l}\text { Huge Gap between } \\
\text { Research And Policy } \\
\text { Development }\end{array}$} & Pearson Correlation & .052 & 1 & $.129^{\circ}$ & -.006 & -.030 & .091 & .016 \\
\hline & Sig. (2-tailed) & .345 & & .020 & .914 & .585 & .099 & .769 \\
\hline & $\mathrm{N}$ & 326 & 326 & 326 & 326 & 326 & 326 & 326 \\
\hline \multirow{3}{*}{$\begin{array}{l}\text { Low involvement of } \\
\text { entrepreneurs waste } \\
\text { management }\end{array}$} & Pearson Correlation & -.066 & $.129^{\circ}$ & 1 & -.019 & .016 & .014 & $.177^{\prime \prime}$ \\
\hline & Sig. (2-tailed) & .232 & .020 & & .737 & .775 & .797 & .001 \\
\hline & $\mathrm{N}$ & 326 & 326 & 326 & 326 & 326 & 326 & 326 \\
\hline \multirow{3}{*}{$\begin{array}{l}\text { poor public attitude } \\
\text { towards waste }\end{array}$} & Pearson Correlation & .091 & -.006 & -.019 & 1 & .086 & .016 & .065 \\
\hline & Sig. (2-tailed) & .100 & .914 & .737 & & .121 & .780 & .242 \\
\hline & $\mathrm{N}$ & 326 & 326 & 326 & 326 & 326 & 326 & 326 \\
\hline \multirow{3}{*}{$\begin{array}{l}\text { Poverty and Ignorance } \\
\text { among Citizens }\end{array}$} & Pearson Correlation & .012 & -.030 & .016 & .086 & 1 & .050 & .077 \\
\hline & Sig. (2-tailed) & .825 & .585 & .775 & .121 & & .367 & .167 \\
\hline & $\mathrm{N}$ & 326 & 326 & 326 & 326 & 326 & 326 & 326 \\
\hline \multirow{3}{*}{$\begin{array}{l}\text { Waste collection per } \\
\text { week }\end{array}$} & Pearson Correlation & -.027 & .091 & .014 & .016 & .050 & 1 & $.137^{\circ}$ \\
\hline & Sig. (2-tailed) & .627 & .099 & .797 & .780 & .367 & & .013 \\
\hline & $\mathrm{N}$ & 326 & 326 & 326 & 326 & 326 & 326 & 326 \\
\hline \multirow{3}{*}{$\begin{array}{l}\text { Non-regulation of waste } \\
\text { management companies }\end{array}$} & Pearson Correlation & -.100 & .016 & $.177^{\circ *}$ & .065 & .077 & $.137^{\circ}$ & 1 \\
\hline & Sig. (2-tailed) & .070 & .769 & .001 & .242 & 167 & .013 & \\
\hline & $\mathrm{N}$ & 326 & 326 & 326 & 326 & 326 & 326 & 326 \\
\hline
\end{tabular}

\section{Conclusion}

The research conducted detected numerous factors and constraints that negatively impact on sustainable waste management in Accra Metropolis. Provision of adequate skip containers, waste collection vehicles and other logistics could prevent indiscriminate waste dumping, burning and other forms of waste disposal to curb the menace of environmental hazards solid waste generates. Introduction of good integrated waste management system could promote more recycling of waste materials into compost, bio energy and other forms of raw materials that could be used by industries as well as reducing environmental pollution. These can be achieved if government focuses attention more on the waste management sector by incorporating prudent policies as well as allocating enough funds for all operations to work efficiently as scheduled to achieve formidable result. Introduction of Public Private Partnership (PPP) in the waste management sector could also help to address some technical, economic and financial challenges in solid waste management.

Acknowledgments: My sincere acknowledgment goes to Ghana government officials and assembly members who were contacted for information and data.

Author Contributions: For research articles with several authors, a short paragraph specifying their individual contributions must be provided. The following statements should be used "X.X. and Y.Y. conceived and designed the experiments; X.X. performed the experiments; X.X. and Y.Y. analyzed the data; W.W. contributed reagents/materials/analysis tools; Y.Y. wrote the paper." Authorship must be limited to those who have contributed substantially to the work reported.

Conflicts of Interest: Declare conflicts of interest or state "The authors declare no conflict of interest." Authors must identify and declare any personal circumstances or interest that may be perceived as inappropriately influencing the representation or interpretation of reported research results. Any role of the funding sponsors in the design of the study; in the collection, analyses or interpretation of data; in the writing of the manuscript, or in the decision to publish the results must be declared in this section. If there is no role, please state "The founding sponsors had no role in the design of the study; in the collection, analyses, or interpretation of data; in the writing of the manuscript, and in the decision to publish the results".

\section{References}


1. Adjei, S.M., 2013. Municipal solid waste minimization through household waste segregation in Bantama, Kumasi. A thesis submitted to the Department of Environmental Science, Kwame Nkrumah University of Science and Technology, Kumasi, in partial fulfillment of the requirement for the award of Master degree in Environmental Scienc.

2. Ansah, B., 2014. Characterization of municipal solid waste in three selected communities in the Tarkwa Township of Tarkwa-Nsuaem Municipality in Ghana, A thesis submitted to the Department of Environmental Science, Kwame Nkrumah University of Science and Technology, Kumasi, in partial fulfillment of the requirement for the award of Master degree in Environmental Science.

3. Asamoah-Okyere, E., 2011. Characterization and composting of solid waste generated in the Aburi Township, A thesis submitted to the Department of Environmental Science, Kwame Nkrumah University of Science and Technology, Kumasi, in partial fulfillment of the requirement for the award of Master degree in Environmental Science.

4. Asase, M., E. Yanful, M. Mensah, J. Stanford, S. Amponsah. 2009. “Comparison of municipal solid wastemanagement systems in Canada and Ghana: A case study of the cities of London, Ontario, and Kumasi, Ghana." Waste Management 29:2779-2786.

5. Batool, S. and M. Nawaz. 2009. "Municipal solid waste management in Lahore City District, Pakistan." Waste Management 29:1971-1981.

6. Bensah, E.C., Kemausuor, F., Miezah, K., Kádár, Z., Mensah, M., 2015. African perspective on cellulosic ethanol production. Renew. Sustainable Energy Rev. 49, 1-11. Available at: http://linkinghub.elsevier.com/retrieve/pii/ S1364032115003299.

7. Chalam, Philippe and Catherine Gaillochet. 2009. From Waste to Resources: World Waste Survey, Economica: Paris.

8. DEA, 2012. National waste information baseline report, Department of Environmental Affairs, Pretoria, South Africa.

9. Fobil, J.N., Hogarh, J.N., 2006. The Dilemmas of plastic wastes in a developing economy: proposals for a sustainable management approach for Ghana. West African J. App. Ecol. 10 (1),

10.Ghana Statistical Service, 2014. Estimation of population of Ghana in 2014, Ghana Statistical Service, Accra, Ghana. 
11. Hristovski, K. L. Olson, N. Hild, D. Peterson, S. Burge. 2007. “The municipal solid waste system and solid waste characterization at the municipality of Veles, Macedonia." Waste Management 27:1680-1689.

12. Kodwo, Miezah. The Waste Management Situation in Accra-Ghana: The Challenges and Prospects. D-Waste. [Online] 2012.

13. MLGRD, 2010b. National Environmental Sanitation Strategy and Action Plan (NESSAP) 20102015, Ministry of Local Government and Rural Development, Government of Ghana.

14. Momoh, J.J. and Oladebeye, D.H. (2010). Assessment of Awareness of Attitude and Willingness of People to Participate in Household Solid Waste Recycling Programme in Ado-Eketi, Nigeria, in the Journal of Applied Sciences in Environmental Sanitation. Jakarta, Indonesia.

15. Ngoc, U and H. Schnitzer. 2009. “Sustainable solutions for solid waste management in Southeast Asian countries."Waste Management 29:1982-1995.

16. OECD. 2010. OECD Environmental Data - Waste. OECD.

17. Okot-Okumu, J., 2012. Solid waste management in African cities - East Africa, Waste Management - An Integrated Vision, ISBN: 978-953-51-0795-8, InTech, http://dx.doi.org/10.5772/50241.

18. Osei-Mensah, P., Adjaottor, A.A., Owusu-Boateng, G., 2014. Characterization of solid waste in the Atwima-Nwabiagya District of the Ashanti Region, Kumasi-Ghana. Int. J. Waste Manage. Technol. 2 (1), $1-14$.

19. Osei, F.B., Duker, A.A., Augustijn, E.-W. and Stein, A. (2010) Spatial Dependency of Cholera Prevalence on Potential Cholera Reservoirs in an Urban Area, Kumasi, Ghana. International Journal of Applied Earth Observation and Geoinformation, 12, 331-339. http://dx.doi.org/10.1016/j.jag.2010.04.005

20. Performance Audit Report of the Auditor-General on Solid Waste Management by Accra Metropolitan Assembly (AMA). Ghana Audit Service. [Online] February 2011.

21. Puopiel, F., 2010. Solid waste management in Ghana; the case of Tamale Metropolitan Area, MSc Thesis, Kwame Nkrumah University of Science and Technology, Ghana.

22. Sankoh, F.P., Yan, X., Conteh, A.M.H., 2012. A situation assessment of socioeconomic factors affecting solid waste generation and composition in Freetown, Sierra Leone. J. Environ. Prot. 3, 562568. 
23. Tai, J., Zhang, W., Che, Y., Feng, D., 2011. Municipal solid waste source-separated collection in China: A comparative analysis. Waste Manage. 31, 1673-1682.

24. Ranjith, K.A., 2012. Sustainable solid waste management in India, A thesis submitted to the Department of Earth and Environmental Engineering, in partial fulfillment of the requirement for the degree of MSc in Earth Resource Engineering, Fu Foundation School of Engineering and Applied Science, Columbia University.

25.UNEP, 2013. Municipal solid waste comparative analysis study in Jubah, South Sudan, United Nations Environmental Programme. Retrieved 28th January, 2015 at <http://unep.org/SouthSudan/>. 26. UN-Habitat. 2009. Solid Waste Management in the World's Cities.

27. UNSD. 2009. UNSD Environmental Indicators - Waste. United Nations Statistics Division. Available at: http://unstats.un.org/unsd/ENVIRONMENT/qindicators. htm (accessed November 2009).

28. Williams, P. (2005). Waste Treatment and Disposal, Second edition, John Wiley and Sons Ltd, Chichester, 380pp

(C) 2016 by the authors; licensee Preprints, Basel, Switzerland. This article is an open access article distributed under the terms and conditions of the Creative Commons by Attribution (CC-BY) license (http://creativecommons.org/licenses/by/4.0/). 